\title{
Caring for the Needy Populations in the Era of Bani Marin (642-870AH/1244-1465AD) (Historical Study)
}

\author{
Dr. Ali ojan Al- madarmeh \\ Al-albayt University
}

\begin{abstract}
This study aims to highlight the role of Bani Marin in caring for needy populations. We do not mean by the needy populations (the poor, the sick, and those with needs only), but rather care for each category of populations that needs care, such as students, scholars, manufacturers, and craftsmen. To achieve these goals, the study refers to contemporary sources and references for that period. The results indicated that the needy populations received a lot of sponsorship from the state, as the state was interested in building care homes, such as hospitals, schools and mosques. Sufi men were a haven for those in need in times of stress and crisis.
\end{abstract}

Keywords: Bani Marin, care, categories, crises, Sufism.

DOI: $10.7176 / \mathrm{HRL} / 51-03$

Publication date: February $29^{\text {th }} 2020$

\section{Introduction:}

Bani Marin belonged to the famous tribe of Zenata, and their original homeland was in the Central Maghreb countries, which is located between Tlemcen and Tahar.The Marinids appeared on the political scene as a major competitor to the Almohad state, and they exerted their efforts to undermine their rule in the countries of the Maghreb countries until the matterrestored for them. Their rule lasted for more than two centuries. These are the most prosperous times for the countries of Maghreb. Their struggle with the Almohads continued for more than fifty-eight years, during which the Marinids managed to overthrow their rule in the countries of Maghreb and Andalusia, until Prince Abu Bakr Yahya bin Abdul Haq al-Marini managed in $642 \mathrm{AH} / 1248 \mathrm{CE}$ to enter the city of Fez, which remained under his rule until 656 AH / 1258AD.Then Prince Yaqoub bin Abdul Haq came, and he ended this phase of the history of the Almohad state in the countries of the Maghreb by seizing Marrakech, the Almohad capital, in 668 AH / 1269AD.

One of the reasons for conducting this study is the distinction of the Marinid era with intellectual, scientific and economic prosperity, as the countries of Morocco were teeming with their trade and the good that came from everywhere, as well as their era witnessed a broad intellectual renaissance that spread throughout the of Maghreb, in order to encourage their sultans and their princes to science and scholars, In their era, the countries of Maghreb witnessed a qualitative shift in social services, as schools, Koranic schools, and care homes for the poor and hospitals for the sick, which encouraged many Andalusians to move to the countries of Maghreb to live in their cities and villages. The study relies in its methodology on a variety of contemporary sources for the period of study, to come up with a valuable historical study, so the general history books, translations, geography, and modern studies are referred to.

\section{Caring as a concept:}

Care refers to the total services provided to the individual in certain cases, which may be social, health or educational, and may take place inside or outside care centers (Badawi, 1996, p.52). Care can also be defined as an organized process that performs a basic function in society that includes social services, based on limited state-sanctioned policies that are directed to individuals and groups (Al Sakran, 2008, p. 143).

\section{Linguistically, Need is defined as:}

In terms of language: linguists have defined it as a need (Al-Farahidi, 2008, Vol. 3, p. 259). Others went on to say that it is the meaning of poverty (Al-Zubaidi, 1975, vol. 5, pp. 494-500), and it also mentioned the meaning of necessity and destitution (Al-Jawhari, 1990, Vol. 1, p. 307). The need was mentioned in the Noble Qur'an with an explicit pronouncement in three places, among which the Almighty said: "There is no need in the soul of Jacob." (Yusuf, 68), and the Almighty's saying: "And in them, you have other benefits. And through them, you satisfy your needs. And on them, and on the ships, you are transported" (Ghafir, 80). As for those who had settled in the homeland before them, and had accepted faith - they love those who emigrated to them, and they find no hesitation in their hearts in helping them. They give them preference over themselves, even if they themselves are needy. Whoever is protected from his selfishness - it is they who are the successful."(Al-Hashr, 9).

As the word "need" was mentioned in the Prophet's Sunnah, we mention, for example, that it was narrated 
fromIbn 'Umar (May Allah be pleased with them) reported: Messenger of Allah (w) said, "A Muslim is a brother of (another) Muslim, he neither wrongs him nor does hand him over to one who does him wrong. If anyone fulfills his brother's needs, Allah will fulfill his needs; if one relieves a Muslim of his troubles, Allah will relieve his troubles on the Day of Resurrection; and if anyone covers up a Muslim (his sins), Allah will cover him up (his sins) on the Resurrection Day".'(Bukhari 2000, p. 533).

\section{Operationally, Need is defined as:}

Al-Shatby defined it as the needs, in terms of relieving the distress, which often leads to embarrassment and hardship, but he does not reach the amount of corruption expected in public interests (Al-Shatby, DT, C2, p. 10). And Abd al-Salam defined it by saying: "The need is what mediates between necessities and supplements." (Abd al-Salam, 1991, Vol. 2, p. 71).

The need is all that individuals and people need to relieve distress. The needy populations are a description that refers to everyone who needs some kind of care, regardless of whether this care is moral, material or social. This care is provided to people in all their cases, whether its weakness or strength, health, disease, riches and poverty, with a focus on the needypopulation's such as the poor, the needy, people with special needs, inmates and vagrants in addition to those who are exposed to disasters and crises. (Al-Saleh, 1999, pp. 44-45).

\section{Islam and caring for needy populations:}

Islam has cared for the needy, and the do-gooder has guaranteed the great reward from God Almighty.The Almighty said: "But seek, with what Allah has given you, the Home of the Hereafter. And do not neglect your share of this world. And be charitable, as Allah is charitable to you. And do not work corruption on earth-Allah does not like the corruptors." (Al-Qasas, 77). The Almighty said: "however does an atom's weight of good will see it, and whoever does an atom's weight of evil will see it" (Al-Zalzalah, 7, 8).The Almighty said: The parable of those who spend their wealth in Allah's way is that of a grain that produces seven ears; in each ear is a hundred grains. Allah multiplies for whom He wills. Allah is All-Bountiful, All-Knowing”(Al-Baqara, 261).

Many of the noble hadiths that urge the Muslim to spend on the poor, the needy, and those with a need to relieve the distress .It was narrated that Abu Hurairah said:” A man came to the Prophet and said: 'O Messenger of Allah , what kind of charity brings the greatest reward?' He said: to give in charity when you are healthy and feeling miserly and fearing poverty and hoping for a long life. Do not wait until the (death rattle) reaches the throat and then say: "this is for so and so, "and it nearly became the property of so and so (the heirs)." (Bukhari 2000, p. 1353).

Also, the Holy Messenger urged for charity because it is a way to escape from the agony of God and the horrors of the Day of Resurrection. Abu Hurairah (May Allah be pleased with him) reported: The Prophet (新) said, "Seven are (the persons) whom Allah will give protection with His Shade on the Day when there will be no shade except His Shade (i.e., on the Day of Resurrection), and they are: A just ruler; a youth who grew up with the worship of Allah; a person whose heart is attached to the mosque; two persons who love and meet each other and depart from each other for the sake of Allah; a man whom a beautiful and high ranking woman seduces (for illicit relation), but he (rejects this offer by saying): 'I fear Allah'; a person who gives a charity and conceals it (to such an extent) that the left hand might not know what the right has given; and a person who remembers Allah in solitude and his eyes well up."(Bukhari 2000, p. 1357).

The Noble Qur'an and Sunnah have focused, in their honorable texts, on caring for the needy so that society can live in harmony and social peace between the poor and the rich, so that it can be a society free of hatred.Islam has put many financial resources to achieve stable resources to care for the poor and needy, such as Zakat, endowment, inheritance and charity. Islam is a social solidarity among all its members so that the Muslim can lead a decent life free from inconveniences, and that charity is based on strengthening brotherhood and love relations between people. The Almighty said:"Accept contributions from their wealth, to purify them and sanctify them with it - and bless them. Your prayer is a comfort for them. Allah is Hearing and Knowing"(AtTawbah, 103).

As for the endowment, it is a financial system that aims to strengthen the social bonds between individuals, which are aimed at the best of the human being and to achieve reassurance for him in his livelihood. By ensuring a decent life for the poor and needy and preserving their dignity without harming the rich (Al-Omar, 2005, p. 43).

\section{The role of the sultans of Bani Marin in caring for the needy:}

The sultans of Bani Marin had a long tradition of serving the public and the private, because they had a great spiritual and religious place in the public and private souls; this affected their social behavior, as there is no doubt that the good biography of some sultans of Bani Marin and their good morals and their keen interest in science, scholars, public and private were an important factor in the interest in needy populations of their time. (Ibn Abi Zara, 1972, p. 91). 
Prince Abdul Haq Bin Mahyo Bin Abi Bakr (592-614 AH / 1195-1217 CE), was known for his piety and is described by justice, famous for piety, righteousness, and blessing.He would distribute food for needy people, looks after the orphans, help the poor, and the vulnerable, and he follows the Sunnah, fasting most days of the year, and always giving praise to Allah (Al-Nasiri, 1954, Vol. 3, p. 8).

Sultan Ya`qub ibn Abd al-Haqq (656-685 AH / 1258-1286 CE) was also fasting, at most of his time perform the optional prayer of his nights, always giving praise to Allah, and don't shed blood and generous (Ibn Khaldun, 2000, vol. 3, p. 79, 80).

Sultan Abu Saeed Othman (710-732AH / 1310-1331AD) proceeding along their lines.He was brave, determined, and generous, honoring the jurists and the people of righteousness, and his son Sultan Ali bin Othman (732-749 AH / 1331-1348 AD) followed his father.

The one called Al-Hassan Al-Marini was a pardon that adheres to religion and loves the people of goodness. He never fell into obscene and did not drink wine, neither in his childhood nor in his old age; he was fair.His approach was followed by his son Abdul Aziz bin Ali (768-774 AH / 1366-1382AD) (Ibn Al-Qadi, 1993, Vol. 2, pp. 461, Vol. 9, p. 171).

These good morals of the Sultans of Bani Marin had an important role in encouraging people to do good and help the needy, the poor, the sick, and the students. This religious tendency helped the sultans to take care of the people with needs. Prince Abd al-Haq Muhyu ibn Abi Bakr was the first sultans of Bani Marin who compassion for the poor and the vulnerable. the year $613 \mathrm{AH} / 1216 \mathrm{AD}$, a great battle took place between him and the owner of Rabat, in which victory was his ally, so he collected the spoils he got, he divided all of him among the tribes of Bani Marin, and he did not take anything from him, so when his sons blamed him for his action, he told them that it was sufficient for them to praise and triumph over the enemies, so that they would rule their people (Ibn Abi Zara, 1972, p. 30).

during the reign of Prince Yaqoub bin Abdul Haq bin Muhyu, he made known expenditures from Bayt AlMal to the poor and needy, and A he imposed a monthly salary for the servants, the poor, and the needy to take it every month from the Jewish tribute, he also ordered that the orphans and charity be given to them by dirhams and food every day, Ashura.He spent many endowments to feed passers-by, those in need, the inmates and travelers.In his era, people felt of unspeakable security, safety, prosperity, gentleness and abundance of grace, and no one thanked him (Ibn Abi Zarra, 1972, p. 33).

So wheat was sold in Maghreb countries for seven dirhams per dirham and barley three dirhams, beans and many legumes there is no one who buys them for their abundance in the markets and fine flour in Fez a quarter of a dirham,honey is three pounds in a dirham, the oil is four pounds in a dirham, and ghee is one and a half pounds in weight, salt is in a dirham and raisins is one and a half dirhams for a quarter, dates are six pounds in a dirham, all because of his goodbehavior and his lovely care for people, and he made a lot of tribute money to care for the sick and blind. (Ibn Abi Zarra, 1972, p. 73).

To alleviate the suffering of the aggrieved and the poor, Sultan Yaqoub bin Abdul Haq ordered to build places to accommodate the poor, the needy, the passers-by, and the needy, especially in the desolate areas far from urban areas, and many endowments were spent on them. In the year $684 \mathrm{AH} / 1285 \mathrm{CE}$ he was built on the grave of his father Abd al-Haq Zawiyat "Tafrift" and ratified by many funds, and he was recommended by many endowments in order to do its full job in caring for the poor and needy. (Anonymous, 1972, p. 110).

Then his son Prince Yusuf bin Abdul Haq was succeeded by Prince Yaqoub bin Abdul Haq who was known for his righteousness and piety. When he became a caliph, distribute money to all tribes, Arabs, Andalusians and other tribes and he gave alms to the poor, and he pardoned the prisoners in all his country, ratified the people, removed the oppression from the people,he removed excises and taxes on the poor, suppressed tyrant and secured roads for people, and removed most of the ranks that were in Maghreb, so the flock was reformed during his reign, prosperity spread and prices were cheap (Hariri, 1987; Ibn Abi Zarra, 1972, p. 33). (Hariri, 1987; Ibn Abi Zarra, 1972, p. 33).

Then Sultan Abu Saeed Othman (710-732 AH / 1310-1331 AD) succeeded him, the Sultan who prospered during his reign throughout Maghreb countries. In his era, the Maghreb countries witnessed a great civilization boom at all levels political, economic, social and intellectual, and this Sultan was venerable scholars and jurists, and built many schools, and was a lover of good and his family. The poor and the needy lived a quiet life, due to the generosity and great attention by him (Ibn Khaldoun, 2000, Vol. 3, p. 88).

And when he took over the caliphate in $710 \mathrm{AH} / 1310 \mathrm{AD}$, he spent the money on the tribes of Bani Marin, the Arabs, the soldiers, the jurists, the scholars, and the poor. He devoted himself to looking at the conditions of his flock, especially the vulnerable and the oppressed.

He abolished taxes, and pardoned the prisoners, except for the corrupt and the murderous, and those who were imprisoned in a legal right.He ordered the distribution of alms to the poor, and thus the lives of the poor became better.Ibn Abi Zarra said: "In his era goodness spread and the life of the poor improved and justice spread" (Ibn Abi Zarra, 1972, p. 399).

Sultan Abu Saeed Othman visited the sick and the funerals and gave the righteous every year the money 
and everything they needed, and he used to spend the endowment money on the poor, if he heard the crying he cried and if he heard the sermon he was reverent.Sheikh Abu Abdullah Al-Meknes was one of his companions, and he was careful not to speak in the sermons where the Sultan was located, because he was crying for God's sake (Ibn Marzuq, 1981, p. 122).

Sultan Abu Saeed used to redeem the captives from his private money, compassion for them and freedom from slavery. Sheikh Abu Abdullah Muhammad bin Ahmed bin Abi Al-Sharaf Al-Sabti was captured during his reign, in Al-Zaqqasea, and the Christians treated them well, but they asked them for a large ransom, so Prince Abu Al-Hassan Al-Marini, son of Sultan Abi Saeed, offered his father Abi Saeed to intervene and redeem them from his wealth, compassion for them. When the enemies knew that the Sultan was the one who would redeem him with his money, they exaggerated the price of the ransom until he reached seven thousand dinars of gold, and the Sultan paid them from his own money. (Harakat, 1980, p. 146).Sultan Abu Saeed was also relieving those who were unable to pay their money to the people and issued an order during his reign to pay the debts of everyone who cannot pay the debt.

He sat himself to judge among the people, heard their complaints, and performed their fairness, so if he prayed Friday, he sat in the mosque, and he presented cases to him and raised complaints to him, so he would judge them himself, and he might sit on Mondays and Thursdays, and he also built the Dome of Justice in the city of Tlemcen and Sabta. Whenever he went to them on a visit, he would sit and listen to people's complaints and take care of their affairs, and he would appoint those who would go to the country in order to report to him on the conditions of people in these countries and their living conditions, so these reports would be submitted to him and he would be the one who inspected the conditions of people in countries.To be from the people of honesty and righteousness in order not to favor anyone, and in order to bring the complaints of the people and their grievances in all honesty, he was not satisfied with that, but he was writing to the judges and preachers in this country about the complaints that brought to him,He also issued an order to meet in each country after Friday prayers its leader, and the judges and all sit down to hear people's complaints, and they will be judged fairly. But if it was difficult for them, he wrote to them to send to him directly in order to rule in him with justice, and he focused on them and promised them intimidation and warning if they did not do so, and he knew that he was carrying out the implementation of justice himself, so he would ride on his own to the oppressed even if he traveled a long distance in order not to hide anything from his subjects and to sleep while he knows that there is no oppressed in his state (Ibn Marzouk, 1981, p. 122, p. 150).

He also bought the mosque of the Abbad of Tlemcen for an eighth of an dinar, and when he bought a woman from the vendors, he said to him: O our Lord, allow us to live here, it is difficult for us to live in a place other than this, so he was merciful to her and to the vulnerable people living in this place that he built houses in this place Of his own money, it was inhabited by the vulnerable and the poor who could not find a home to live in (Ibn Abi Dinar, 1967, p. 300).

His son Sultan Ali bin Othman, who is called Abu Al-Hasan Al-Marini, followed his policy (732-749 AH / 1331-1348 AD), who was known for his generosity and, especially for the poor, the elderly and students. He has ordered that homes for the poor and needy be built. And they were given the clothing every year regularly (Ibn Marzouk, 1981, p. 284).

Sultan Abu Al-Hassan was also providing food, sweets, incense and goodness to the people of the Prophet's birthday to celebrate this happy occasion and in his desire to alleviate the poor on this great day, and the celebration of the Prophet's birthday usually begins officially in the month of Rabi' al-Awwal after the Maghrib prayer,where the Sultan holds a celebration, they invite people, especially the poor, to sit and sit in a well-known arrangement and eat food and fruits, then bring cakes and sweets, and then reciters recite the Qur'an and chants recite the poems and praises of the Prophet. Ibn Abi Dinar, 1967, pp. 306, p. 307).

In the interest of the poor and the flock, he built a mosque in every place on the road between the cities and built a corner next to it, arranging food and drinks for travelers, the poor and the needy; and he ordered the endowment to be spent on it. Abu Al-Hasan Al-Marini was also giving gifts to the pimps, soldiers, judges, imams, preachers, entourage and the poor on each Eid Al-Fitr and Eid Al-Adha feasts.On the night of Eid AlMouled, one hundred thousand dinars are distributed among the jurists, students, preservation, and whoever attends the Al-Mouled, so they each take from ten to one hundred dinars (Ibn Abi Zara, 1972, pp. 314, 348; Harakat, 1980, p. 158).

$\mathrm{He}$ also had a great role in serving the Qur'an and caring for students and readers. Sultan Abu Al-Hassan sent to the Haram al-Makki a Qur'an that he wrote in his hand and took charge of its refinement among the major readers.Ibn Marzuq mentioned this in his book, and he said: "While we are skilful of the craftsmen's skill in covering and covering the plates of gold, jewels and rubies, he also used the textured leather with gold lines and above them the silk linen covers." Ibn Marzuk also mentioned that Sultan Abi Al-Hassan sent with the Mushaf a large sum of sixteen thousand five hundred dinars of gold in order to spend it for the care of the Qur'an (Ibn Khaldun 2000, c. 7, p. 42; Ibn Marzuk, 1981, pp. 37, 193).

Sultan Fares Abu Al-Anan (749-759 AH / 1348-1357 AD) also took care of the needypopulations, and 
worked to meet their needs, so he built the great corner outside Bab Fez and prepared it for strangers, vagrant and for those who had to stay in it such as merchants, the poor and the needy and provided them with more food,drink and all that the traveler needs. (Alahmar, 1987, p. 69),

Al-Wenchiri pointed out that there are some lands that are locked in for the poor and poor in Maghreb, called the land of the poor; it was planting and distributing its crops to the poor and needy in this place.He also pointed out that a man in Maghreb granted property to one of the hospitals and acted to treat patients and feed the poor. Al-Wenchiri adds that a man in the Maghreb countries named Ibn Arif gave some of his properties in his country and made consideration of the endowment for the preacher of the mosque (Al-Wenchiri, 1978, c. 7, pp. 38, 82).

From the above, it is clear to us that the princes and sultans of Bani Marin exerted their efforts in caring for the needy, especially the poor.They also responded firmly to injustice, so those in need lived a comfortable life during their reign, as the poor, needy, or orphaned person in the era of Bani Marin was barely guaranteed by the state.

7. The role of the sultans of Bani Marin in facing crises and disasters:

In the era of BeniMerine, the countries of Maghreb suffered from many crises and natural disasters such as earthquakes, fires, famines and epidemics, which claimed the lives of many people that is why the Sultans of Bani Marin worked hard to alleviate their impact on the people.

During the reign of Sultan Abi Saeed Othman bin Abdul Haq (614-637 AH / 1217-1239 AD), sedition abounded in the countries of the Maghreb to disperse the tribes and their differences, and most of them rejected obedience and divided the group.The strongest of them encroached upon the weak, so the bandits of the tribes of Sinhajah, Europe and Ghamara were attacking the villages due to neglect and corruption.The cost in the country intensified, and when Sultan Abu Saeed saw this and realized what people were suffering because of these conditions, the elders of Bani Marin and their leaders gathered to resist injustice, and imposed on every tribe money and agricultural crops that they pay every year for their protection. The sheikhs of the city of Fez, Meknesa, Rabat, Taza and Qasr Ketama agreed on well-known funds that they would pay to protect and secure the roads, so the people were safe in their role (Ibn Abi Zara, 1972, p. 37).

During the reign of Sultan Yusuf bin Yaqoub Al-Marini, a severe famine occurred in the year (693 AH / 1293 AD), and the Sultan made his effort to relieve people from their hunger and destitution, and he spent a lot of money to face this crisis, until this crisis ended (Ibn Abi Zara, 1972, p. 384). The country suffered severe drought in the year $711 \mathrm{AH} / 1311 \mathrm{AD}$ until the cultivation decreased and people did not find anything to feed on it, so the Sultan went out with the people to perform the invocation for the rain prayer, so he walked on his feet until he reached the mosque, the jurists, the righteous, and the readers with him, and distributed funds and charity,In the year $723 \mathrm{AH} /$ 1323AD the Great Souk of Al-Attarin was burned in Fez, so Sultan Abu Saeed ordered to build and renovate it again ,It was built and renovated from the door of the Al-Attarin School to the head of Aqabat Al-Jazzarin,And he set up a great iron gate and built on top of it an honorable wall as if it were the door of a great city. It was also a nice idea to build homes for perfumers in this market, so the perfumers and their families lived there and were not shared by anyone (Ibn Marzouk, 1981, p. 284).

After this crisis in the countries of Maghreb, its people suffered a severe famine in 724 AH /1322 AD. Prices have risen sharply, for example, the price of wheat has reached sixty dinars, flour is four dirhams, an ounce of meat is half a dirham, and vegetables does not exist as long as that has lasted from the beginning of the year.In this distress, Sultan Abu Saeed and his congregation made unimaginable goodness. So he opened the farm stores and put it out for sale. The wheat was sold for four dirhams, and people sell it for fifteen dirhams.And he ordered alms, and he still separated them throughout the days of distress.In the winter, he orders the distribution of clothing for the poor, the weak, and the needy. He also orders those who have died from strangers to be prepared and shrouded in new clothes, and their burial is to be done in the best way (Ibn Abi Zara, 1972, pp. 37, pp. 398, 401).

In the year $725 \mathrm{AH} / 1324 \mathrm{AD}$ a great torrent occurred in the valley of the city of Fez; demolishing the fence, hitting the gardens, uprooting trees, demolishing the arches and homes, demolishing the Al-Sabbaghen market, destroying the large arch on which the Bab al-Silsila market is located, and about 730 people died in it.After the torrent was over, Sultan Abu Saeed Othman ordered the construction of the Great arch on which the Bab al-Silsila market was built, and the shops were built again and the al-Sabbagh market was built, and ordered the construction of the Mosque of Hazza Ibn Barquqah (Al-Nasiri, 1954, c 2, P. 54).

\section{Bani Marin and the establishment of social care homes:}

The role of Bani Marin did not stop; it was not limited to caring for the poor and the needy only; rather, they expanded to build many service facilities that were providing services to all needy populations such as the poor, the needy, vagrants, travelers, students, scholars, and expatriates. These establishments diversified and their roles varied according to the goal for which they were built, such as; schools, mosques, charity corners (Zawaya), 
bemarstanat (hospitals), etc. We will discuss some details about the role of these facilities in providing their services to the community.

First: Schools:

The schools that were established during the Bani Marin era are the most prominent evidence of the intellectual and scientific renaissance that this era witnessed;it also indicates the degree of attention given to education by the Marinid dynasty. One of the first schools built by the Sultans of Bani Marin was the School of Al-Saffarain, which was the first school built during their reign, built by Sultan Yaqoub bin Abdul Haq Al-Marini (656-685 $\mathrm{AH} /$ 1258-1286 AD). The reason for calling it by this name; because it was built next to the Al-Saffarain market in relation to what they made of brass utensils, Sultan Yaqoub appointed the teachers, spent on their students, and provided each teacher with a bookcase, and also made them rooms for students to stay in and a mosque (AlFassi, 1973, p. 25; Ibn Marzouk, 1981, p. 405).

The Sultan built another school similar to the School of Al-Saffarine in Marrakesh, and it came in the best way. He also built another school in Meknes called the Al-Qadi School, and Al-Wenchiri referred to another school in Tlemcen called the Yaqoubi School in relation to Sultan Ya`qub al-Marini. (Al-Wenchiri, 1978, vol. 8, p. 175).

In the year $720 \mathrm{AH} / 1320 \mathrm{AD}$, Sultan Abu Saeed Othman built the Madaba al-Bayda or the new Fez, arranging and organizing it in the best way, and the Sultan spent a lot of money on it, in order to do its full role.Sheikh Abdullah bin Al-Qasim Al-Mezwar established in Fez the Al-Attarin School in the year( 723 AH / 1323 A.D.), and he bought a number of buildings for her, so there were nearly fifty houses in it, and it was one of the most beautiful schools of Bani Marin, distinguished by its beautiful decoration and in which the Sultan appointed professors and paid them gifts. He appointed those who used to serve the school,teachers and students (Al-Nasiri, 1954, Vol. 3, p. 206).

He also established the Al-Musbahiya School in relation to al-Imam Masbah Bin Abdullah. He is the first to be appointed to teach in this school. The school contains a hundred and seventeen rooms. He also established the School of Al-sab'een in Fez and was named so because it was studying the seven readings, and he also built the Bouanania School in Meknes (Harakat, 1980, p. 153).

Sultan Abu al-Hasan al-Marini, the most sultans interested in science, established the "al-Sahraj" school during the reign of his father in $721 \mathrm{AH} / 1321$ CE.He also established the Al-Tala'a School in Sala in the year $723 \mathrm{AH} / 1323 \mathrm{AD}$ next to the Great Mosque, and on its surface he created a water basin, with a bowl furnished with mosaics in the middle, and a small tank of marble in the middle, and there is a prayer house inside the courtyard, and set up twenty-four student houses distributed between two floors .He also established in every country of AL-Maghreb a school to teach students, so he established the city of Tazi, Meknes, Sala, Tangier, Sabah, Safi, Azemour, Agmat, Marrakesh and Tlemcen, schools of different sizes according to the needs of each of these countries, and established a school of medicine in the city of Salé (Ibn Marzouk, 1981, P. 406; El-Fassi, 1973, p. 30).

Sultan Abu Annan al-Marini followed them, and he established the Ananiyah School in 750 AH / 1349 AD and it was the pride of Marinid architecture, and it took seven years to build. Sultan Abu Annan visited it upon its completion. And he said his famous saying:

Satisfaction is completely priceless; it's ok for the expensive to be precious.

Sultan Abu Annan spent many endowments on its students, and built a bakery, stables and shops next to it, to spend on it (Al-Kettani, 2004, c. 4, p. 225).

\section{Second: Mosques:}

The sultans of Bani Marin were interested in building and restoring mosques to be fully serviced by the guests of Rahman. One of the most important of these mosques was the Al-Jami Mosque in the new city of Fez, which was built by Sultan Yaqoub bin Abdel Haq Al-Marini in 677 AH / 1278 AD, also Sultan Abu Al-Hasan AlMarini built the Al-Abbad Mosque near the Mausoleum of the Righteous Guardian Abu Madian Shuaib built the Sultan Abu Anan Mosque of Sidi Al-Halawy (Al-Hariri, 1987, p. 320).

The Al-Qarawiyyin Mosque was restored during the reign of Sultan Yaqoub bin Abdul Haq. These reforms were carried out in the major mosques under the supervision of the Sultans of Bani Marin, and some of them even donated their own money to complete these reforms.SultanYa'qub ibn Abd al-Haq donated two gold anklets, weighing five hundred dinars of gold, to contribute to the rebuilding of the underground wall of the AlQarawiyyin Mosque, and was appointed to supervise its construction the jurist Abu Ghaleb al-Mughaili (Ibn Abi Zarra, 1972, c1, p. 98, 413).

The mosque of Al-Andalus was restored in Fez in $692 \mathrm{AH} / 1292 \mathrm{AD}$, and it underwent a massive restoration process, and in $695 \mathrm{AH} / 1295 \mathrm{CE}$, Sultan Yusuf Yaqoub ordered to repair, restoration, and renovation of the Al-Andalus Mosque and the water was connected to it from the Masmouda River (Al-Juznai, 1967, p. 66). 
Give more attention to the mosques in order to play their role in serving the people to the fullest;Sultan Abi Annan Faris ordered that the masts in the mosques of the city of Fez be placed on the mast with wood and during the day a flag was raised upon it during prayer times and at night a torch was lit to show people to enter the prayer time.Sultan Abi Saeed Othman built the Mosque of Al-Saffarain, the mosque of AL-na'ameh and Sawmaa', each of them very high, good and splendid, and built many mosques in Al-Baida' city and Mansoura, and in the city of Sebta, built the mosque connected to the palace, which is a busy mosque, and the Mansour mosque in Marrakech. it notes that the role of mosques in the era of Bani Marin that he was not only performing the prayers, but the mosques played an important social role that they play in serving the poor and needy (Ibn Marzuq, 1981, p. 404).

Third: the charity corners (Zawaya):

The sultans of Bani Marin concerned with building the corners, especially the corners of the elders, who were righteous to bless them. They spent a lot on it, and the corners had great social significance in the era of Bani Marin, as it was a haven for the poor and the needy who could not find what they need, so they found what they need in these places that were specially prepared to receive the needy, the poor, the vagrants and the expatriates.SultanYa'qub ibn Abd al-Haqq built many corners in the deserted places on the roads between cities, and many people spent on them. Sultan Abu al-Hasan al-Marini built a good corner in Salé, and a lot of money was spent on it in order to be able to play its role in serving the poor and those in need, and its construction was completed in late Dhu al-Hijjah from 739 AH / 1338AD.Abu al-Hasan al-Marini built al-Mashwarinchritycorner, al-Qorja charity corner, and a number of arches and facilities in Al-Maghreb (Ibn al-Khatib, 1967, p. 170).

Sultan Abu Anan Faris built the corner of the hermits in the city of Salé, and it served as guest houses, where travelers used to provide them with what they need in their travel, as the poor and needy went there and found all the food, drink, and clothing they needed, and it included a beautiful garden and many rooms for overnight And a large prayer hall had two large doors, one of which was heading towards the city of Shalla and the other towards the city of Sala.

He also built a large charity corner of the city of Sebta and prepared it for the poor and needy. He built the great charity corner outside the door of the city of Fez and returned it to strangers and to those who had to stay in it such as the merchants, vagrants and others. This corner was well-built with a lot of decoration, with a large area, multi-dwelling, and its silence was one of the most elegant silos in the city of Sebta (AL-Sabti, 1983, p. 31).

Fourth: The ParmarasanaH (Hospitals):

The Bimaristan is the place where the patients were treated to recover from their diseases (Ibn Manzur, 1993, c. 6, p. 192). Bimarstanat spread in the countries of the East, as well as in the countries Al-Maghreb, especially in the era of Bani Marin who was very interested in building it. Sultan Yaqoub bin Abdel Haq built hospitals in the countries of the Maghrib and the lunatics, spending money on them and all the necessary food, clothing, and money, and he ordered the doctors to check their conditions and treat the sick, and provide them with what they needed, and spent the poor money every month from the Jewish tribute (Ibn Abi Zara, 1972, p. 298). Sultan Yusuf bin Yaqoub built (698 AH / 1298 AD) a bamarstan in the city of Mansoura, and next to it he built markets and baths and he ordered to build of a large mosque next to it (Ibn Khaldun, 200, c. 7, p. 221).

Sultan Abu al-Hasan al-Marini also built in Fez Maristanat to treat patients. He renewed one of these hospitals that was near Caesarea in Fez.He was also take care of patients with skin diseases and bone pain patients and other diseases (Al-Juznai, 1967, p. 26).In the Marinid era, these hospitals were managed by a group of people who were appointed,such as; Muhammad Ibn al-Qasim bin Abi Bakr al-Qurashi al-Maliki, who took over the administration of Maristan Fez, which was Established by Abu Anan al-Marini (Ibn al-Qadi, 1973, p. 191).Among the well-known Bimarstanat attributed to Bani Marin, AziziBimaristan is in the city of Rabat, which is attributed to its founder, Sultan Abi Faris Abdul Aziz bin Ali bin Othman Al-Marini, and its construction dates back to the eighth century AH. (Sahar, Al-Sayed, 1996, p. 147).

\section{Fifth: Public facilities:}

The public utilities are intended to facilitate the livelihoods of people in society. The Sultans of Bani Marin took care of the state's infrastructure, so they took care of building arches, baths, and markets, dragged water into cities, and built bridges over rivers. Sultan Yaqoub bin Abdul Haq took care of the services in the state, establishing Qanater, such as arch of Wadi Al-Naja, arch of Marine, and others (Ibn Abi Zara, 1972, pp. 62, 91).

When he built the new city of Fez in the year 679 AH / 1280 AD, he built markets in it from Al-Qantaras' door to AyounSanhajahs' door, and built a great bathroom thereand he ordered his workers and ministers to build houses, so each of them built a house, as was built during his reign of the Kasbah Meknes and its palace and mosque. During the reign of his son Yusuf bin Yaqoub, markets, baths and marstans were built in the city of Mansoura in 698 AH / 1298 AD (Ibn Khaldoun, 2000, c. 7, p. 221). 
Bani Marin took great care in constructing the arches; among the arches that were rehabilitated during their reign was the arch of Abu Tuba, repaired by Abu Saeed Othman Al-Marini. Abu Saeed also built arch AlSabbaghine, Rumaila, and Al-Silsilah, especially after the flood that struck the city of Fez in 725 AH / 1324 AD and destroyed many of the houses, shops, and arches (Al-Juznai, 1967, p. 31).

Sultan Abu Al-Hasan Al-Marini took care of the construction of the arches, and he established the archofWadiRadat, the arch of Bani Basil, the arch of Al-Wadi, the arch of Al-Raseef, the arch of Sateef in Tlemcen, and the arch of Bab al-Jiad.Also he care about water and work to deliver it to the cities in order to make it easier for people, so Abu Al Hassan spent a lot of money to get drinking water to Salé as well as the city of Tlemcen. The number of what was created for watering in the era of Bani Marin in the city of Sabteh was twenty-five waterings (Al-Sabti, 1983, p. 40).

Abu al-Hasan al-Marini constructed the wall, on which the water was carried to the city of Salé, and it is called the Wall of Arches, and water was flowing over it from the eyes of the pool outside the city of Sala on large miles extending from Qibla to Al-Jawf, on a huge building. The water runs over it so it drops to the ground when it rises, and rises from it if it falls, and the water of the small river runs in its squares (Al-Nasiri, 1954, p. 176).

\section{Sufism and the care of the needy in the era of Bani Marin.}

The era of Bani Marin witnessed a great emergence of Sufi thought .Sufism spread all over Maghreb countries, and entered every home.People used to love them, bless them, and resort to them.Everyhistorical researcher in the Maghreb countriesknows the great role of Sufism in social life throughout the ages, especially the era of Bani Marin.

They have ordered to build homes for the needy and sanatoriums of the poor and people with disabilities at their expense. The animal welfare culture has spread, for the Sufi Muhammad ibn Musa al-Halfawi established a home to treat sick animals (Al-Hadrami, 1964, p. 40).

It was reported that Sheikh Abu Bakr bin Abi Ishaq Ibrahim bin Abbad had donated more than his inheritance from his father for the sake of God, and he was generous, so he used to make food for the poor and vulnerable and distribute it to them(Al-Hadrami, 1964, p. 68).

Also, Sheikh Yusuf bin Yaqoub Al-Bayousi used to spend a lot of money, and in his illness he distributed among the needy relatives and acquaintances a thousand and three hundred dinars, and he divided all his money among his heirs.As the Sufi mystic Abu Abdullah Muhammad Al-Janati used to serve the sick stranger, and was trying to help him, and scholars and the public were praising him in Lebanon .As for Sheikh Ali Al-Lajaei was seeking to help the people and the needy, as he used to distribute charity, support the oppressed, and provide the daily needs of the needy to cover their needs such as food, drink, clothing, and he used to support young people who are unable to marry and help them to marry (Bin Qunfuth 2002, pp. 85, 119, 120).

Sheikh Abu Muhammad Abdullah bin Hamad spent a lot of money on the weak, strangers and people with disabilities, as Sheikh Ahmed bin Al Hassan Al Ghammari was passing through the Nedrumah market on Thursday filling a jug of water in the afternoon hours an hour in the extreme heat , and he goes to people to water them. While Sheikh Muhammad bin Yusuf bin Shuaib Al-Senussi, he recommended people to preserve noble social values (Ibn Ghazi, 2007, p. 114; Ibn Maryam, 1908, p. 32).

All people were referring to the Sufi Sheikhs in the era of Bani Marin,especially if things got more difficult for them at the time of famines and epidemics, when a famine occurred in $673 \mathrm{AH} / 1274 \mathrm{AD}$, people were referring to the great Sufi house, Abu Zaid Al-Hazmiri, wanting to eat and drink, and they found what they needed there (Ibn Aishun, 1997, p. 218).Also Sheikh Abd al-Wahid al-Sunhaji and his wife Fatima were among the great mystics of Al-Maghreb countries in the era of BaniMarin.His wife sought to fulfill people's needs, as she and her husband were digging wells to fetch water for the benefit of humans and animals (Ibn Qunfudh, 2000, 131).Also Sheikh Abu Abdullah Muhammad bin Musa Al-Halfawi (d. 758 AH / 1356 AD), this man was very favored by Sultan Abi Anan Al-Marini, as he was commanding people to do good and forbid them from evil, Muhammad ibn Musa al-Halfawi was very sensitive to the weak and the needy, providing the needy with all the food, clothing and drink he needs(Al-Kettani, 2004, Vol. 3, p. 346).

Also, Sheikh Muhammad bin Yusuf bin Omar bin Shuaib (d. 895 AH / 1490 CE) was very important in society, he was ordering his family for charity, especially in the time of famines, and he was urging his followers to increase charity, especially in times of hardship, such as Sheikh Yusef bin Omar Al-Anfasi (d. 761 AH / 1359 AD) from one of the great jurists of the city of Fez (Al-Kattani 2004, c 3, p. 189).

He was ordering his family for charity, especially in the time of famines, and he was urging his followers to increase charity, especially in times of hardship, such as Sheikh Yusef bin Omar Al-Anfasi (d. 761 AH / 1359 AD) from one of the great jurists of the city of Fez (Al-Kattani 2004, c 3, p. 189). Sheikh Muhammad bin Ya la Al-Tawoudi taught the boys, so he took the reward from the children of the rich and returned it to the the poor children and washed their clothes himself in a bowl that he had in the office and sewed them, and thus he was known as a tailor (Al-Tanbakti, 2004, c 2, p. 204). 


\section{Conclusions:}

The needy populations in the era of Bani Marin, of different types and different conditions, were given wide publicity in the ra of Bani Marin,whether at the state level or at the individual level by wealthy community members, including scholars and the leaders of Sufism, Whether at the state level or at the individual level by wealthy community members, including scholars and the leaders of Sufism. The Marinid era witnessed a qualitative shift in caring for those in needby the state's interest in building care homes for these groups, such as schools, mosques, public facilities, they established water channels, baths, arches, and worked to provide drinking water, markets, shops, and homes for merchants near the markets. Sufi men were a destination for those in need in times of stress and crises.

The results indicated the interdependence of the Marinid community, and that caring for the needy were taking a large part of their interests, that was manifested during the crises and calamities that afflicted the countries of the Maghreb from time to time. It is clear, thanks to the efforts of the state represented by the efforts of the princes and sultans and the efforts of the wealthy, the elite, the scholars and the great men of Sufism. Thus;Because of those efforts, the people of Maghreb overcame the crisis in a short period of time, due to the charity work they had done.

\section{References}

1. Ibn al-Ahmar, Abu al-Walid Ismail bin Yusef. (1987). Natherfi shaear min nazminiwa'iiahalzuman. Editor Mohamed Radwan. (2nd floor). Beirut. Lebanon. Al-Resaleh institution.

2.Al-Bukhari, Abu Abdullah Muhammad bin Ismail bin Ibrahim Al-Jaafi (256 AH / 869 CE). (2003). Sahih Bukhari. (I 1). Cairo. Dar Al-Bayan Al-Hadethah.

3. Badawi, Ahmed Zaki, (1996). A dictionary of social science terms. Lebanon. Lebanon Library.

4 Al-Tanbakti, Abu al-Abbas Ahmad Baba bin Ahmed bin Omar bin Muhammad (d. 963 AH / 1055 CE). (2004). NaylAlaibtihajBitatrizAldiybaj. (1st ed.) Editor Ali Omar. Cairo. Religious Culture Library.

5. Al-Jaza'ni, Abu al-Hasan Ali (d. 766 AH / 1374 A.D.) (1967). JiniZahrat Alas fi Bina' MadinatFas. Rabat. Royal Press.

6. Al-Gohari, Ismail bin Hammad. (1990). Alsahah Taj AllughatWasahahAlearabiat, Editor Ahmed Abdel Ghafour Ata, Beirut. Lebanon. Dar Alelemllmalayeen.

7. Al-Hariri, Mohamed Essa. (1987). Islamic and Andalusian history in the Marinid era (2nd edition). Kuwait. Dar Al-Qalam for Publishing and Distribution.

8. Al-Hadrami, Abu Abdullah Abdul-Muhaimen bin Muhammad bin Abdul-Muhaimen (d. 749 AH / 13448 CE ).(1964). AlsulslAleadhbWalmunahlAl'ahlaa. Edited by Mohamed El-Fassi. (Part One). Cairo. (DN).

9 Ibn al-Khatib, Lisan al-Din Muhammad bin Muhammad bin Abdullah bin Saeed bin Abdullah bin Ali bin Ahmed al-Salmani (d. 776 AH / 1374 CE). (1967). NafadatAljarab fi EalalatAlaightirab. Cairo. Dar Al Kateb Al Arabi for Printing and Publishing.

10. Ibn Khaldun, Abu Zaid Abd al-Rahman bin Muhammad al-Hadrami (d. 808 AH / 1405 CE). (2000 AD). Tarikh Ibn KhaldunAlmusamaaAleibarWadiwanAlmubtadaWalkhubr fi 'ayaamAlearabWaleujamWalbarburwamineasirihim min DhwyiAlsultanAl'akbur. Edited and review by SuhailZakar, Beirut. Lebanon. Dar Alfker.

11 Ibn Abi Dinar, Abu Abdullah Muhammad ibn Abi al-Qasim al-Qayrawani (1110 AH / 1698 CE). (1966). Al Muounis in African and Tunisian News(1st edition). Tunisia. The protected Tunisian state press.

12. Al-Zubaidi, Muhammad Murtada Al-Husseini. (1975). The Bride's Crown is a Jewel of the Dictionary. (40c), 2nd edition, edited by Abdel-Halim El-Sawy. Kuwait.

13.Ibn Abi Zarra, Abu al-Hasan Ali bin Abdullah bin Abi Zara al-Fassi (d. 762 AH / 1326 CE). (1972). AldhakhiratAlsuniyat fi TarikhAldawlatAlmariniati. Rabat. Al-Mansour Printing House.

14 ....... (1972). Al-Anis, al'anisalmutaribbirawdalqurtas fi 'akhbarmulukalmaghribwatarikhmadinatmaknas. alrabat. Rabat. Al-Mansour House for Printing and Paper.

15. Salem, Sahar Al-Sayed Abdel Aziz (1996). MadinatRibatAlfath fi AlttarikhAl'iislamiiMundhNashayihaHataaNihayatEasrBaniMaryn. Alexandria. University Youth Foundation.

16.Sabti, Abu Abdullah Muhammad bin al-Qasim bin Muhammad al-Sabti (he was alive in (825 AH / 1421 AD). (1983). .AikhtisarAl'akhbarEamaaKanBisibtat Min SuniyiAlathar. Edited by Abdul Wahab bin Mansour. (2nd edition). Rabat.

17.Sukran, Turki bin Abdullah. (2008). NudawirAlwaqf fi RieayatAlmieuqina. Saudi. Islamic University.

18.8. Al-Shatby, Ibrahim bin Musa bin Muhammad, Almuafaqat fi 'UsulAlsharieat. Edited by Abdullah bin Draz. Beirut. Lebanon. Dar Al-Ma'refah.

19- Al-Saleh, Muhammad bin Ahmed. (1999). Social Care in Islam and its Applications (1st edition), Riyadh. Saudi. 
20 Abd al-Salam, Izz al-Din (1991). Rulers rules for people's interests, revised by Taha Abdel-RaoufSaad, Cairo. (Dn).

21.Al-Omar, Ayman Mohamed. (20 March 2005). The endowment and its role in economic development. Kuwait University, Journal of Sharia and Kuwaiti Islamic Studies, No. (60).

22. Ibn Aishoun, Abu Abdullah Al-Shatrat. (1997). AlruwdAleutarAl'anfasBi'akhbarAlsaalihin min 'ahlFasi. Edited by Zahraa Al-Nadhar. (1st floor). Aldar Albaida'. New Success Press.

23.Ibn Ghazi, Muhammad ibn Ahmad ibn Muhammad ibn Abdullah (d. 919 AH / 1513 CE). (2007). alrawdalhitun fi 'akhbarmuknasatalzaytun.edited by Ata Abu Rayya. And Sultan bin Malih Al-Asmari (1st edition). Cairo. Religious Culture Library.

24. Al-Farahidi, Abu Abd al-Rahman al-Khalil bin Ahmed. (2008) Book of the Eye. Edited by Mahdi AlMaktoumi Ibrahim Al-Samarrai Cairo. Dar Al-Hilal.

25. Ibn al-Qadi, Abu al-Abbas Ahmad bin Muhammad bin al-Afiyah al-Meknasi (d. 1025 AH / 1616 CE). (1973). jadhwatalaiqtibas fi dhakar min halinminal'aelam fi madina. Maghreb, West, sunset. Dar AlMansour for Printing and Publishing.

26. Ibn Qunfath, Abu Al-Abbas Ahmed bin Al-Hassan bin Ali bin Al-Khatib (d. 810 AH / 1407 AD). (2002). Anas Al-Faqir and Izz Al-Hoger (edited by Abi SahlNajahAwadSiyam (1st edition), Cairo, Dar AlMoqattam for Printing and Publishing

27. Al-Kettani, Abu Abdullah Muhammad bin Jaafar bin Idris (d. 1345 AH / 1926 CE). (2004), salwatal'anfaswamuhadathatalkiasbiman 'aqbar min aleulama' walsulha' bifas(1st edition). Edited by Abdullah Al-Kettani and Hamza bin Mohammed Al-Tayeb. Al-Maghreb, Dar Althaqafah.

28. Ibn Marzuq, Muhammad ibn Ahmad ibn Muhammad al-Tlemcani (d. 781 AH / 1379 CE). (1981). almasanadalsahihalhasan fi mathirwamuhasinmawlana 'abialhasn. Edited by Maria Jesus Pegira. Algeria. National Printing and Publishing Company.

29. Ibn Maryam, Abu Abdullah Muhammad bin Muhammad bin Ahmed (d. 1064 AH / 1653 CE). (1908). albustan fi dhakaral'awlia' waleulama' bitalmsana. aljazayiru. almutbaeatalthuealibiat.. Algeria. Al-Thaalaby Press.

30.Ibn Manzur, Muhammad bin Makram Ali Jamal Al-Din (d. 711 AH / 1311 CE). (1993). Lessan Al-Arab. (3rd floor). Beirut. Lebanon. Dar sader.

31.Al-Nasiri, Abu al-Abbas Ahmed bin Khalid al-Nasiri, Alaistiqsa' Li'akhbarAlmaghribAl'aqsaa (1954). Edited by Ja 'far al-Nasiri, Al-Maghreb, Dar al-Kitab.

32. Marrakeshi, Abdel WahedMarrakchi. (1963). Almaejab fi Talkhis 'AkhbarAlmaghribi, Edited by Professor Mohamed El-Erian. Cairo. Egypt. Islamic Heritage Revival Committee. 